Науковий вісник Чернівецького університету імені Юрія Федьковича: Історія. - № 2. - 2018. - С. 38-49. History Journal of Yuriy Fedkovych Chernivtsi National University. - № 2. - 2018. - pp. 38-49.

DOI https://doi.org/10.31861/hj2018.48.38-49

hj.chnu.edu.ua

УДК 94(477.85-2Хот):352.075]«1918»

(C) Oleksandr Rusnak ${ }^{1}$ (Chernivtsi)

(C) Mykola Ilkiv² (Chernivtsi)

(C) Mykola Holovlov 3 (Khotyn)

\title{
NEW SEAL OF DISTRICT CHIEF: TO THE CENTENARY OF UKRAINIAN AUTHORITYIN KHOTYN REGION
}

Abstract. A number of anniversaries associated with the events of the Ukrainian Revolution of 1917 - 1921, as well as the discovery of the seal of Khotyn district chief (starosta), have prompted once again to address the problems of Ukrainian state formation in Khotyn region, in particular during the period of existence of the Ukrainian State of Hetman Pavlo Skoropadskyi. The seal belonged to Khotyn district starosta, whose duties were first assigned to O. Suharenko, and later - to P. Izbytskyi. The period of its use may be limited, respectively, since May 28 to November 12, 1918.

Keywords: the Ukrainian State, metallic seal under the sealing-wax, Khotyn district, district chief (starosta), P. Izbytskyi.

Олександр Руснак (Чернівці)

Микола Ільків (Чернівці)

Микола Головльов (Хотин)

\section{НОВА ПЕЧАТКА ПОВІТОВОГО СТАРОСТИ: ДО СТОРІЧЧЯ УКРАЇНСЬКОЇ ВЛАДИ НА ХОТИНЩИНІ}

Ряд ювілеїв, пов'язаних із подіями Украӥнської революиії 1917 - 1921 рр., а також віднайдення печатки Хотинського повітового старости спонукають вкотре звернутися до проблематики українського державотворення на Хотинщині, зокрема в період існування Української Держави гетьмана Павла Скоропадського. Печатка належала Хотинському повітовому старості, обов'язки якого спершу були покладені на О. Сугаренка, а згодом - на П. Ізбииького. Наказом Міністерства внутрішніх справ від 28 травня 1918 р. мирового суддю О. Сугаренка призначено в.о. старости Хотинського повіту. 315 червня того ж року Хотинський повіт був переведений в адміністративне підпорядкування Подільської губернії. Ймовірно, повітовий староста прибув у Хотин уже в липні, коли територію регіону контролювали австро-угорські війська. Діяльність повітового старости

к.і.н., асистент кафедри історії України Чернівецького національного університету імені Юрія Федьковича.

PhD in History, Assistant Professor, the Department of History of Ukraine, Yuriy Fedkovych Chernivtsi

National University.

orcid.org/ 0000-0003-2921-3029

E-mail rusnak.o.85@gmail.com

2 к.і.н., асистент кафедри історії стародавнього світу, середніх віків та музеєзнавства Чернівецького національного університету імені Юрія Федьковича.

PhD in History, Assistant Professor, the Department of Ancient History, Medieval and Museology, Yuriy

Fedkovych Chernivtsi National University.

orcid.org/0000-0002-1501-876X

E-maililkiv_chnu@ukr.net

3 Хотинський міський голова, краєзнавець

Mayor of Khotyn, Local Historian

orcid.org/0000-0002-4231-5065

E-mail hotyn2019@gmail.com 
П. Ізбицького чітко фіксується в документах впродовж 10 - 12 листопада. Він інформував місиеве населення про наступ румунських частин $і$ закликав зберігати спокій. Висловивщи протест проти окупаиії міста і повіту як території Української держави, П. Ізбицький був змушений покинути Хотин і переправився на лівий берег Дністра. Таким чином, період використання печатки може бути обмежений часом з 28 травня до 12 листопада 1918 р.

Ключові слова: Українська Держава, металева печатка під сургуч, Хотинщина, повітовий староста, П. Ізбицький.

Formulation of scientific problem and its significance. Aim of the article. In the context of the commemoration of the centenary of the Western Ukrainian People's Republic and the holding of Bukovyna Assembly (Viche), a number of events are planned, which is the evidence of a significant increase of scientific and public interest in the problems of the Ukrainian state formation in the region. Against this background, will be worth mentioning one of the less well-known and not so widely-developed events in the historiography - an attempt to establish the power of the Ukrainian State of Hetman Pavlo Skoropadskyi in Northern Bessarabia. To this we are also pushed by an important relic - the seal associated with these events, which, with the assistance of Kamianets-Podilskyi Mayor M.Ye. Simashkevych and First Deputy of Mayor H.I. Horshunov returned to Khotyn and will become an adornment of the museum exposition in the future.

The seal has a round shape (Fig. 1). It is bronze (possibly brass) and consists of two parts: a) the body of the seal in the form of a proper low cylinder with a diameter of 3.62-3.70 cm and a height of 0.7-0.8 cm; b) the rod is of a lengthenly pyramidal shape with a square base of $0.68 \times 0.68 \mathrm{~cm}$. The total height of the product is $3.49 \mathrm{~cm}$; weight $-69,4 \mathrm{~g}$. A circle has a dense inscription written in Ukrainian in a mirror image: «KHOTIN DISTRICT STAROSTA». In the centre there is a trident. It is noteworthy, that the name of the city was transmitted with a characteristic mitigation in the ancient form «Khotin», «Khotin'», which has survived in the people's speech of Khotyn district and Podilia to our days ${ }^{1}$.

Analysis of recent research. Today there are no special researches about the presence of the district starosta of the Ukrainian state in Khotyn region, but fragmentary information on this is mainly contained in articles or monographs, devoted to the events of 1918, Khotyn uprising of 1919, and general works on the history of the region.

The first mention about Hetman's starosta in Khotyn dated back to 1948. In particular, A. Yurchenko in the work «Khotyn Uprising (To the History of Northern Bessarabia Peasants' Struggle Against the AustroHungarian and Romanian Invaders in 1918 - 1919)», referring to the materials of Chernivtsi regional archive wrote: «In the first days of November last Austro-Hungarian parts purified Khotyn region ... By that time the hetman's «government» living in Ukraine last days sent to Khotyn his district starosta ${ }^{2}$. No less tendentious, in the spirit of that time Soviet ideology, were the following words of the author: «With great hope Khotyn peasants watched their future. ... They did not recognize the authority ... of Hetman's starosta .... $\rangle^{3}$. A. Yurchenko once again remarked about starosta (P. Izbytskyi), giving a passage from his encrypted telegrams on 7 and 8 November to Kyiv, which reported on Romanian attacks and marked «the general anxiety of the population, who did not want Romanians» ${ }^{4}$. In our opinion, there was absolutely no basis for accusing the hetman's commander in «counter-revolutionism» and «every kind of opposition to the organization ... of the rejection to Romanian invaders $\rangle^{5}$, which are given there. At the same time, the work contains photocopies or texts of important documents, a number of which relates precisely to our problem ${ }^{6}$.

A few works by Soviet scholars were supplemented with publications of archival documents collections and memoirs of participants in those events. The most fundamental gatherings include «Khotyn Uprising (Collection of Documents and Materials)», published jointly by the Institute of History of the Academy of Sciences of the Moldavian SSR in Chisinau in 1976, Central State Archive of the Moldavian SSR, Chernivtsi Regional State Archive and Chernivtsi Regional Local History Museum. In spite of the efforts of the organizers to submit the events of 1918 - 1919 under the angle of region population struggle «for Soviet power ${ }^{7}$, some of the materials published by them contain valuable information ${ }^{8}$.

Brief references about attempts to establish the Ukrainian authority in 1918 in Khotyn region are in the work by K. Tsypko «The Great October Socialist Revolution and the Struggle of Bukovyna Workers for the Power of the Soviets and Reunification with Soviet Ukraine» ${ }^{9}$, article by I. Piddubnyi «Materials of 
the Central State Archive of Supreme Bodies Power and Management of Ukraine on events of 1918 - 1919 in Khotyn District» ${ }^{10}$, collective monographs «Bukovyna: Historical Essay» ${ }^{11}$, «Khotyn Region: Historical Essay» ${ }^{12}$ and «Bukovyna in the Context of European International Relations (Since Ancient Times to the Middle of the XXth Century)» ${ }^{13}$.

Despite the existence of these studies, we must state that, as a whole, there is not much knowledge about the activity of Hetman's district starosta in Khotyn. The most debatable issue is about his appointment to the post and the beginning of work, which is especially important for the date of the seal.

Presenting main material. Let's consider the first problem. Sometimes the formation of the provincial and district institutes is May-August 1918 (on May 14 - the hetman's decree «... instead of the provincial commissars the posts of the district starostas were introduced, and the district commissars were dismissed by the order of the Ministry of Internal Affairs, and the district starostas were appointed to their place» ${ }^{14}$ and the Council of Ministers Resolution about the provision to the Minister of Internal Affairs of a loan in the amount of 10 million karbovantsi «... for the issuance of advances to the Provincial and District Starostas .... ${ }^{15}$; on August $10-\langle\ldots$ Hetman approved the law on the staff and the composition of provincial and district starostas departments, and as well as provision of funds for their activity"16. Among «The List of Provincial and District Starostas» Khotyn was also in the list of 2nd level districts ${ }^{17}$. We made a preliminary conclusion, that Khotyn district starosta could be appointed in May-August 1918. For example, «... Podilia Provincial Starosta ... Serhii Ivanovych Kisilov» was appointed on May $13^{18}$, and the district starostas of Podilia in May 3, 1918 (to fulfil temporary duties) ${ }^{19}$ or permanent in May 29, $1918^{20}$ (although they began to perform their duties not immediately $)^{21}$.

The very idea of the appointment of the district's starosta in Khotyn, who was under the control of the Austrian administration, obviously, was also born in those days. This is confirmed by the materials of M. Hedin's article with references to the funds of the Central State Archive of the Supreme Bodies Power and Administration of Ukraine: «In May 18, 1918, from the public of Soroky Zemstvo M. Pelavaniuk to the Ministry of Foreign Affairs of the Ukrainian State, a memorandum was received in which the author spoke about the measures, which had to be taken in the event of the accession of Bessarabia to Ukraine. In particular, it was emphasized that it is necessary to send a starosta and two assistants to Khotyn district, adding to it four more parishes of Soroka district. It was also emphasized on the need for the immediate accession of Bessarabia to Ukraine $\rangle^{22}$.

Our assumptions are confirmed by «The Order on the Appointment and Dismissal» of the Ministry of Internal Affairs of the Ukrainian State of May 28, 1918, No. 42: «Appointed: peace judge Suharenko Oleksa Maksymovych - to perform the duties of Khotyn starosta since May 26, 1918 $»^{23}$. But O. Suharenko, obviously, was still under the control of the Ministry of Internal Affairs. As, according to the article mentioned above, I. Piddubnyi writes (the material with reference to the Central State Archive of the Supreme Power and Administration of Ukraine): «... In June 15, 1918, the decree of the Minister of Internal Affairs on the administrative subordination of Khotyn district to Podilia province came out $\rangle^{24}$. And in June 20, 1918, according to Podilia historians statement, one of 13 district chiefs of Podilia O. Suharenko (later P. Izbytskyi) was appointed in Khotyn ${ }^{25}$. However, in «the orders on appointment and release» of June 12, 1918, No. 109, O. Suharenko was released «... according to his request since June 5, $1918 \ldots\rangle^{26}$. Thus, the lower chronological limit of the production of the starosta's seal may not be more ancient than May 26, 1918.

There is another problem: when did the Hetmanate's representative start to fulfil his duties? Paying attention to the fact, that the fate of Bessarabia at that time was solved primarily on the international level between the Hetman's government in Kyiv and the Romanian cabinet in Bucharest, we can assume the date of the probable arrival of O. Suharenko or P. Izbytskyi in Khotyn in July 1918 (at least not before). This opinion follows from a letter of Hetmans Foreign Affairs Minister P. Doroshenko to his vis-a-vis in Romania, dated of July 11, 1918, in which is mentioned the need to establish common borders and friendly relations between the two states ${ }^{27}$.

This thesis, too, was confirmed in the article by I. Piddubnyi: «In one of the appeals of Khotyn district starosta of the Ukrainian state of November 11, 1918, No. 38 to the commander of the 2nd cavalry division in Khotyn states that the Ukrainian State, guided by the regulation, that Romania annexed Bessarabia with the exception of Khotyn district, and by the agreement with the Romanian government in late July 1918 announced the accession to the Ukrainian State of Khotyn district with its further inclusion in 
Podilia province. As it stated in this document, this was done on the basis of requests from more than 100 rural communities, that expressed a similar desire in their verdicts. Actually, the representative of the Ukrainian State district starosta Izbytskyi ruled the district, who asked the Romanian command to clarify the situation $\rangle^{28}$.

However, there was still an Austrian command in the region, without the consent of which to resolve the issue would finally be problematic. On this occasion, we can cite a fragment of a letter from the provincial starosta of Podilia S. Kisilov to the Ministry of the Interior Affairs on the prevention of the Austrian militaries the authority of Ukraine in Khotyn district of July 10, 1918: «The local Austrian command, referring to non-receipt of any orders, declared, that they had nothing against the arrival of the district starosta [in] Khotyn, but in order not to interfere with the order of the Austrian authorities, otherwise it will be suggested to leave the district» ${ }^{29}$. That is, if Khotyn district starosta arrived in Khotyn in July 1918, he would not receive real power.

On the other hand, the day of arrival of hetman's starosta to Khotyn district, according to Soviet historian A. Yurchenko, is November 7, $1918^{30}$. Although the documentary reasons to believe this, the author has not given. On this occasion, we can only add, that in the report of Khotyn district zemstvo administration, to the district zemstvo meeting of November 10 (October 28, Old Style) 1918 only the fact of arrival is stated, but no date is given ${ }^{31}$ (see annex A). And November 7 as the day of the arrival of P. Izbytskyi to Khotyn, is confirmed only by the memoirs of T. Levandiuk ${ }^{32}$ (a participant of Khotyn uprising from the village of Dankivtsi), which were recorded in 1973 and published in the collection «Khotyn Uprising (Collection of Documents and Materials)». Paying attention to the inaccuracies, made in these memoirs (P. Izbytskyi is named as the representative of «Petliurian gangs ${ }^{33}$ ), and their certain tendentiousness (the hetman's starosta is baselessly accused of cooperating with the Romanian militaries, who, as if with his consent, «... committed a bloody attack on the villages of the district $\left.»^{34}\right)$, it is impossible to put the line under this problem.

As for the specific actions of Khotyn district starosta, we can say the following. On the basis of P. Izbytskyi's announcement of November 10 (October 28, Old Style) $1918^{35}$, we learn about an attempt to inform the local population about the presence of Romanian troops at neighboring stations of Larga and Lypkany and their expected arrival in Khotyn soon. In such circumstances, the Ukrainian State starosta asked Khotyn residents «... to remain in complete quietness ...», and the militia «... must accurately perform its official duties not to allow any performances, from which side they did not go out ...». Finally, he called for a strong suppression of any attempts to spread disorder.

But since the evening of that very day Khotyn was captured by Romanian troops ${ }^{36}$, it was not possible for Hetman's representative to realize the conceived. Predatory cruel methods of occupation power soon caused a significant increase in anti-Romanian disposition in the region and caused the collisions.

From the report of Khotyn district starosta to Hetman's Minister of Internal Affairs No. 42 of November 20,1918 , we learn about «... verbal, and then a written protest against the occupation of the city and the district, as a territory of the Ukrainian state .... ${ }^{37}$, which he made to Romanian militaries colonel Moruzi and general Davidoglu after their entry into Khotyn.

The same document gives us reasons to assert, that on the last day of staying of Khotyn district starosta P. Izbytskyi at his work place became November 12, 1918 (at 5 p.m.) ${ }^{38}$. The hetman's official reported, that after warning from the Romanian general, he left Khotyn at that time, having passed the power to the district zemstvo council head ${ }^{39}$. Taking into consideration the earlier instructions from S. Kisilov: «In the case of pretensions about the transfer of power to the Romanians, who will rely on force, making subordinate to the power, after having drawn up the appropriate act of transfer, leave for Kamianets $\rangle^{40}$, such actions can be called planned.

Local representatives of the Ukrainian state tried to keep Khotyn district under control. In particular, Podilia starosta S. Kisilov on November 13, 1918 appealed to the Ministry of Internal Affairs to allocate a monetary loan for this purpose ${ }^{41}$.

It is also necessary to mention other little-known attempts to spread the Ukrainian authority in Khotyn district at that time. Among orders of the Ministry of Military Affairs «On Appointment and Release» dated of April 24, 1918, No. 110 (On Headquarters) in $§ 9$ «Khotyn district military commander Kolesnikov, appointed as a temporary compliance officer of Khotyn district commandant $\rangle^{42}$. There have also been cases of approval of Ukrainian ideas in transport and education (see annexes B, C, D, E, F, G). 
Conclusions. Thus, the seal on the basis of the emblem and the title of the post should be associated with the Ukrainian State of Hetman Pavlo Skoropadskyi. It belonged to Khotyn district starosta, whose duties were first assigned to O. Suharenko, and later - to P. Izbytskyi. Accordingly, the period of its use may be limited by the time since May 28 to November 12, 1918.

\section{ANNEXES}

\section{Annex $A$ \\ ПЕРЕЧЕНЬ}

докладовъ и вопросовъ, представляемыхъ на разсхотръніе Хотинскаго Уъзднаго Чрезвычайнаго Земскаго Собранія 27 октября 1918 года.

1/ Докладъ № 1, о политическомъ положеніи Хотинскаго уЊзда, созданнаго уходомъ АвстроВенгерскихъ войскъ изъ предЂловъ уђзда.

Printed according to:

Державний архів Чернівецької області (далі - ДАЧО) [Chernivtsi Regional State Archive (next ChRSA)]. - Ф. 42. - On. 2. - Cnp. 153. - Арк. 8 .

\section{ДОКЛАДЪ № I.}

о политическомъ положеніи Хотинскаго уъзда, создавшемся съ уходомъ Австро-Венгерскихъ войскъ изъ предъловъ уъзда.

Съ очищеніемь уђзда отъ Австро-Венгерскихъ оккупаціонныхь войскь, открылся вопросъ о дальнъйшей судьбъ нашего уђзда. Рђшивъ созвать въ возможной скорости Земское Собраніе для рьшенія вопросовъ, связанныхъ съ текущими событіями, Управа приняла всъ зависящія оть нея мъры для поддержанія порядка и законности и обезпеченія безопасности населенія. Съ этой цълью Управа приняла на себя, какъ единственный правомочный органъ власти, управленіе всъмъ уъздомъ, о чемъ ею и выпущено было 23 сего мъсяца спеціальное объявленіе. Принимая на себя права и обязанности по управленію, Управа твердо върила, что населеніе уъзда спокойно и разумно отнесется къ измънившимся условіямъ и что никакихъ анархическихъ движеній ожидать не приходится. Изъ этихъ соображеній Управа твердо стала на той точкъ зрђнія, что для поддержанія порядка и законности, иноземнаго вмђшательства не нужно. Совершенно достаточно усилить милицію, необходимую для борьбы съ преступными элементами. Путемъ сношеній со всьми волостными земствами, Управа старалась проводить этотъ взглядъ и убъдить населеніе въ необходимости порядка и спокойствія. Къ сожальнію это Управђ не вполнђ удалось и въ различныхъ мъстахъ уђзда снова возраждается анархія и проявляють свою дъятельность темныя сила.

Вопросъ о дальньйшихъ мъропріятіяхъ долженъ былъ быть внесеннымъ на усмотръніе собранія, но въ настоящее время условія измънились: положеніе уъзда стало еще болъе неопредъленнымь; въ Хотинъ прибылъ Повитовый Староста Украинской Державы, объявившій о присоединеніи уњзда къ Державъ Украинской, въ тоже время, въ Бричанахъ, Начальникъ І-ой Румынской кавалерійской дивизіи объявлявтъ о присоединеніи Хотинскаго уъзда къ Румыніи. Такъ или иначе изолированнымъ уъздъ по видимому больє не будетъ и всь функціи по управленію и въ томъ и другомъ случађ отъ земства отпадутъ и Управа вернется къ завъдыванію своими чисто земскими дълами. Полагая, что окончательное ръшеніе вопроса о принадлежности земли Хотинской, можеть состояться лишь по постановленію международной конференцій и признавая настоящее положеніе дъль временнымъ н преходящимъ, Управа представляеть все вышеизложенное на усмотрђніе Собранія и просить:

$$
\text { ДАЧО [ChRSA]. - Ф. 42. - On. 2. - Спр. 153. - Арк. } 9 .
$$

1/ одобрить дъйствія Управы;

2/ подтвердить стремленіе уЊзда къ возсоединенію съ единой Великой Россіей;

3/ открыть кредить на усиленіе милиціи въ размърь до 50.000 руб. и 4/ воздъйствовать на населеніе въ смысль поддержанія порядка и законности. 
Предсидатель Управы

Члены

И.о. Секретария

ДЪло № 85/1918 г. 1 сен.

ДАЧО [ChRSA]. - Ф. 42. - On. 2. - Сnp. 153. - Арк. 9 зв.

УКРАЇНСЬКІ

Annex B

Право-бережні

залізниці

КЕРОВНИЧІЙ РУХУ

Новоселицької лінії

Жмерінск. відділу

Іюля 2 дня 1918 р.

№ 1086

Ст. Окниця.

Г. Предсъдателю Хотинской Уъздной Земской Управы.

Сегодня случайно на столбъ прочелъ объявленіе № 5094 отъ 6 Іюня н.с. подписанное Вами и командиромъ Ц. иК. 7 Генеральной команды съ изложеніемъ ряда мъръ по продовольственному вопросу.

Порядокъ этотъ, рознящійся отъ мъропріятій предппринятыхъ по этому вопросу на Украинъ, совершенно не даетъ укаваній какой порядокъ въ отношеніи вывоза и ввова, а равно и перевозки въ предЂлахъ края долженъ соблюдаться на желъзныхъ дорогахъ.

Между тъмъ желъзная дорога отъ Волчинца до Новоселицы и отъ Окницы до Дондюшанъ, какъ эксплоатируемая Украиной, продолжаеть руководствоваться распоряженіями, получаемыми изъ Кіева и, полагаю, ставить подъ сомнъніе вопросъ о возможности выполненія указанных мъропріятій.

Въ интересахъ дЂла сообщаю вышеизложенное и покорно прошу заполнить этоть пробъль. Желательно дабы такія мъропріятія ръшались сь участіемъ полномочнаго представителя жельзной дороги и дабы, въ цЊляхъ провъденія ихъ въ жизнь, я ставился немедленно и непосредственно въ извъстность, какъ лицо уполномоченное руководить жельзнодорожными перевозками этого участка.

РЕВИЗОРЬ СЛУЖБЫ ДВЖЕНІЯ

$$
\text { ДАЧО [ChRSA]. - Ф. 42. - On. 1. - Cnp. 150. - Арк. } 69 .
$$

\section{Annex $C$}

Господину Австро-Венгерскому Коменданту гор. Хотина.

Въ отвътъ на предложеніе Ваше отъ 6/4 апрђля сего года извЊщаю, что о появленіи украинскаго офицера въ Окницђ, протестующего противъ забора австрійскими властями артиллерійскихъ принадлежностей, принадлежащихъ 8 арміи Земству ничего неизвъстно и въ этомъ направленіи никакихъ распоряженій никому недавалось.

Предсьдатель Управы

Секретарь

ДАЧО [ChRSA]. - Ф. 42. - On. 1. - Cnр. 149. - Арк. 44.

ХОТИНСКАЯ

Annex D

УЂЗДНАЯ

ЗЕМСКАЯ УПРАВА.

екретарское отдъленіе

1 Столь

Марта 26/6 дня 1918 г. 
№879

г. Хотинъ.

Бессарабской губерніи

Господину Австро-Венгерскому Коменданту гор. Хотина.

Въ отвътъ на предложеніе Ваше отъ 6/4 апрђля сего года извъщаю, что о появленіи украинскаго офицера въ Окницъ, протестующаго противъ забора австрійскими властями артиллерійскихъ принадлежностей, принадлежащихъ 8 арміи Земству ничего неизвЂстно и въ этомъ направленіи никакихъ распоряженій никому равно и Управленію Уъздной Милиціи не дълалось.

Предсьдатель Управы

Секретарь

ДАЧО [ChRSA]. - Ф. 42. - On. 1. - Сnp. 149. - Арк. 45.

Українське товариство

\section{Annex E}

Просвіта

6 вересня 1918 p.

№ 401

Ст. Окниця

Пів. Зах. Заліз.

Хотинская

Уездная Земская Управа

31 авг 1918

Вход. № 6131

До Хотинського повітового Земства

В додаток до листа Т-ва «Просвіта» від 31 серпня під № 396 спішимо повідомити, що питання про утворення будівельного фонду гімназії при ст. Окниця в 100.000 карб. одпадає, позаяк ці кошти має дати Держава чи одночасовим асігнуванням чи шляхом внесення щорічнов сміту державних видатків. У зв'язку з зміною справи Товариство прохає вирішити справу про допомогу на оборудовання гімназії в розмірі 25000 карб., або одноразового асігнованого, або шляхом внесення в сміту періодично.

Про постанову Земства прохаємо повідомити за превідію Просвіти.

Голова Просвіти

ДАЧО [ChRSA]. - Ф. 42. - Оп. 1. - Спр. 147. - Арк. 86, 86зв.

Українське товариство

\section{Annex F}

Просвіта

... серпня $1918 \mathrm{p}$.

№ 396

Ст. Окниця

Пів. Зах. Заліз.

Хотинская

Уездная Земская Управа

22 авг 1918

Вход. № 5882

До Хотинського повітового Земства

Виконуючи бажання населення Окниці і $1 і ̈$ широких околиць Хотинського, Сороцького й частини Білецького повітів, в котрих живе більше 400 тисяч українського народу, Окницьке Товариство «Просвіта» в місяці вересні р. 1917 одкрило при ст. Окниція мішану для хлопців і дівчат гімназію. 
На прохання «Просвіти» ствердити гімназію одержана відповідь Департаменту Середньої Школи Міністерства Освіти, від 5 червня с. р. ч. 1628/9002, що «Міністерство Освіти дало повні права державних середніх шкіл українській мішаній гімназії Т-ва «Просвіта» в Окниці»... Крім того цими днями постановою Міністерства Освіти гімназія зазначена в сітку державних українських гімназій і переведена на державні кошти.

Але ж, щоб гімназія рахувалася державною потрібно виконати де-які умови, а головне закласти будівельний фонд на гімназію в 100.000 карб. і 25000 карб. на оборудовання гімназії - до початку біжучого академічного року і не пізнійше 15 вересня с.р.

Хоча торік гімназія утримувалася на кошти «Просвіти», але, на жаль, вона не має змоги внести, або забезпечити такої суми грошей, позаяк кошти «Просвіти» складаються 3 членських внесків $\mathrm{i}$ випадкових прибутків; до того ж вони через ріжні несприяючі обставини підупали. Таким чином «Просвіта» може дати на дальше утримування гімназії тільки незначну допомогу.

Виконати де-які умови, а саме заарендувати будинок під гімназію на більш-менш довший срок і придбати у власність шматок землі в 1-2 десят. під будівлю гімназії «Просвіта» може взяти на себе.

Зважаючи на велику потребу їснування гімназії в Окниці для просвітної мети народів Хотинського й сусідніх Сороцького й Білецького повітів, позаяк Окниця прилучена до Хотинського повіту і є осередок цих повітів, а середніх шкіл в цій великій околиці зовсім немає, а також бажаючи утримати в Окниці гімназію, цей культурний форпост українського народу на бесарабщині, Окницьке Товариство «Просвіта» звертається до Хотинського Земства 3 щирим проханням допомогти в цій справі шляхом закладення будівельного фонду гімназії в 100.000 карб. і 25000 карб. на оборудовання гімназії, або иншим шляхом допомоги, аби забезпечити їснування гімназії, і про свою постанову по цій справі сповістити Просвіту, яко мога в близчий час, аби вона мала змогу до початку учебного року зробити відповідні по цій справи заходи.

Голова Просвіти

Писар

ДАЧО [ChRSA]. - Ф. 42. - On. 1. - Cnp. 147. - Арк. 87, 8736.

Румынья

Annex $G$

Хотинская Уездная

Земская Управа

1919 года іюня 6 дня

№ 653

Г-ну Префекту Хотинс. Уезда

Въ ответъ на предложенье Ваше отъ 5 іюня с.г. за № 2641 основанное на телегравномъ приказе Г-на Министра Делегата отъ Правительства въ Бессарабью за № 1217./919. честь имеемъ ответить, что со стороны Хотинской Уездной Земской Управы не было дано никакой спеціальной делигацій, прошенья, теторы, или протеста для представленья на мирную конференцію въ Парижъ Г-мъ Александру Карловичу Шмидту и Александру Николаевичу Крупенскому.

При чемъ совоокупляемъ что въ Октябре месяце 1918 года после того какъ ушли Австрійскіе войска и передъ приходомъ Руминских въ Хотинскій уездъ Прибылъ съ Украины одинъ повитовый староста а имено Избиндскій и попросиль отъ Уездной Земской Управы передачи администраціи уезда, мотивируя темъ что Хотинскій уездъ остается присоединенъ къ Украине, Упомянутая Управа не имея возможности решить этоть вопрось сама созвала Чрезвычайное Земское собрание въ день 28 октября 1918 года. Упомянутое собрание для того чтобы избавится оть требованья предъявленнаго упомянутымъ Повитовымъ старостой определило: Составить протоколь чтобы работы остались так какъ были передъ воиной и указывая что стремления уезда есть къ восоединенью единой Великои Россіи.

Упомянутый Повитовый Староста возвращаясь въ Украину а имено когда Румынскіе воиска занимали уездъ захватиль съ собою три копию съ составленом собраньемъ протокола.

Приладья при семъ для сведенья копию съ протокола.

Председатель

$\ldots$

Секретарь

ДАЧО [ChRSA]. - Ф. 42. - On. 1. - Сnp. 147. - Арк. 37, 3736. 

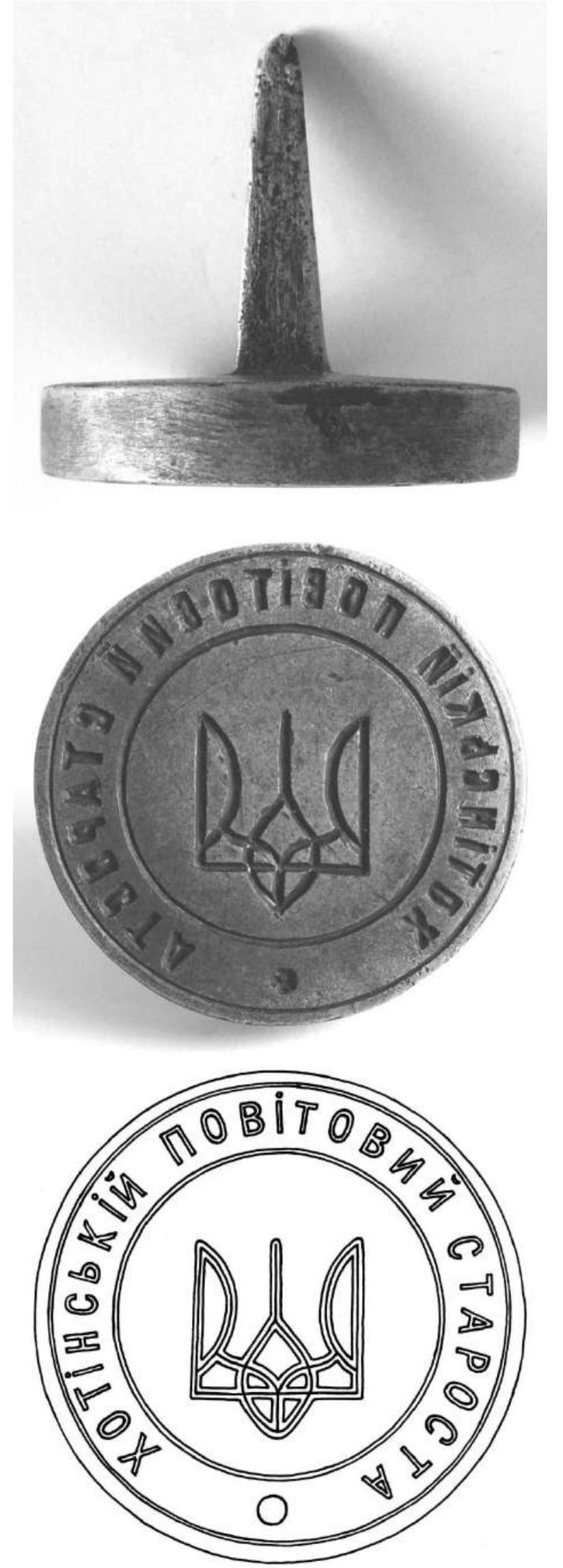

Fig. 1. Metal seal under the sealing-wax of Khotyn district starosta of the Ukrainian State 
1 О. Добржанський, Ю. Макар, О. Масан, Хотинщчина: Історичний нарис [Khotynshchyna: Historical Essay], Чернівці, Молодий буковинець, 2002, с. 56.

2 А. Юрченко, Хотинское восстание (К истории борьбы крестьян северной Бессарабии против австро-венгерских и румынских оккупантов в 1918 - 1919 гг.) [Khotyn Uprising (On the History of the Struggle of the Peasants of Northern Bessarabia against the Austro-Hungarian and Romanian invaders in 1918 - 1919)], Киев, Украинское издательство политической литературы, 1948, с. 38.

3 А. Юрченко, Хотинское восстание, с. 38-39.

4 А. Юрченко, Хотинское восстание, с. 40.

5 А. Юрченко, Хотинское восстание, с. 42.

6 А. Юрченко, Хотинское восстание, с. 43.

7 Хотинское восстание (Сборник документов и материалов) [Khotyn Uprising (Collection of Documents and Materials)], Кишинев, Штиинца, 1976, с. 3.

8 Хотинское восстание (Сборник документов и материалов), с. 56-57, 285-292.

9 К.Г. Ципко, Велика Жовтнева соиіалістична революиія і боротьба трудящчих Буковини за владу Рад та возз 'єднання з Радянською Україною [Great October Socialist Revolution and Struggle of the Working People of Bukovyna for the Power of Soviets and Reunion with Soviet Ukraine], Чернівці, МВО УРСР, Чернівецький державний університет, 1958, с. 97-98.

10 І. Піддубний, Матеріали Центрального державного архіву вищих органів влади та управління України про подіï 1918 - 1919 рр. у Хотинському повіті [Materials of the Central State Archive of the Supreme Governments and Government of Ukraine on the Events of 1918 - 1919 in Khotyn District], in «Історична панорама», Чернівці, 2009, ч. 2, http://www.info-library.com.ua/books-text-10329.html

11 Буковина: історичний нарис, [Bukovyna: Historical Essay], Чернівці, Зелена Буковина, 1998, с. 221.

12 О. Добржанський, Ю. Макар, О. Масан, Хотинщина: Історичний нарис, с. 193.

13 Буковина в контексті європейських міжнародних відносин (з давніх часів до середини XX сm.) [Bukovyna in the Context of European International Relations (Since Ancient Times to the Middle of the XX century)], Чернівці, Рута, 2005, с. 378.

14 Нариси історії державної служби в Україні, [Essays on the History of Civil Service in Ukraine], Київ, Ніка-Центр, 2008, с. 190; Державний вістник (Київ), 1918, №6, 26 травня, с. 1.

15 Державний вістник (Київ), 1918, №7, 29 травня, с. 1.

16 Нариси історії державної служби в Україні, с. 192-193.

17 Державний вістник (Київ), 1918, №36, 17 серпня, с. 3.

18 Державний вістник (Київ), 1918, №8, 31 травня, с. 1.

19 Державний вістник (Київ), 1918, №8, 31 травня, с. 3.

20 Державний вістник (Київ), 1918, №16, 18 червня, с. 1.

21 С.Л. Калитко, О.М. Кравчук, Поділля у період гетьманату 1918 р.: консервативна модель внутрішньо політичної стабілізації [Podilia During the Hetmanate of 1918: a Conservative Model of Internal Political Stabilization], in «Наукові записки Вінницького державного педагогічного університету імені Михайла Коцюбинського. Серія: Історія», 2008, вип. 13, с. 246.

22 М. Гедін, Українсько-румунські відносини напередодні та в період гетьманування Павла Скоропадського [Ukrainian-Romanian Relations on the Eve of and During Hetmanization of Pavlo Skoropadskyi], in «Вісник Київського національного лінгвістичного університету. Сер.: Історія, економіка, філософія», 2012, вип. 17, с. 111.

23 Державний вістник (Київ), 1918, №12, 9 червня, с. 2.

24 І. Піддубний, Матеріали Центрального державного архіву вищих органів влади та управління Украӥни про подіï 1918 - 1919 рр. у Хотинському повіті, http://www.info-library.com.ua/books-text-10329.html

25 Формування та діяльність місиевих державних адміністрацій та самоврядування в період Украйнської революиії 1917 - 1920 рр.: матеріали круглого столу, м. Кам'янець-Подільський, 2 липня 2015 р., Кам'янецьПодільський, 2015, с. 42-43.

26 Державний вістник (Київ), 1918, №23, 18 липня, с. 2.

27 А. Юрченко, Хотинское восстание, с. 122.

28 І. Піддубний, Матеріали Центрального державного архіву вищих органів влади та управління України про події 1918 - 1919 рр. у Хотинському повіті, http://www.info-library.com.ua/books-text-10329.html

29 О.М. Кравчук, I.I. Ратушняк, К.В. Завальнюк, Подільський губернський староста Сергій Кисельов (1877 - 1937) у документах епохи [Podilia Provincial Starosta Serhii Kiselov (1877 - 1937) in the documents of the epoch], Вінниця, ТОВ «Нілан-ЛТД», 2016, с. 126.

30 А. Юрченко, Хотинское восстание, с. 38. 
31 А. Юрченко, Хотинское восстание, с. 126.

32 Хотинское восстание (Сборник документов и материалов), с. 286.

33 Хотинское восстание (Сборник документов и материалов), с. 286.

34 Хотинское восстание (Сборник документов и материалов), с. 287.

35 А. Юрченко, Хотинское восстание, с. 43.

36 А. Юрченко, Хотинское восстание, с. 42.

37 А. Юрченко, Хотинское восстание, с. 129.

38 А. Юрченко, Хотинское восстание, с. 129.

39 А. Юрченко, Хотинское восстание, с. 129.

40 О.М. Кравчук, І.І. Ратушняк, К.В. Завальнюк, Подільський губернський староста Сергій Кисельов (1877 - 1937) у документах епохи [Podilia Provincial Starosta Serhii Kiselov (1877 - 1937) in the documents of the epoch], Вінниця, ТОВ «Нілан-ЛТД», 2016, с. 199-200.

41 С.Л. Калитко, О.М. Кравчук, Поділля у період гетьманату 1918 р.: консервативна модель внутрішньо політичної стабілізації [Podilia During the Hetmanate of 1918: a Conservative Model of Internal Political Stabilization], in «Наукові записки Вінницького державного педагогічного університету імені Михайла Коцюбинського. Серія: Історія», 2008, вип. 13, с. 249.

42 Державний вістник (Київ), 1918, №3, 21 травня, с. 2.

\section{Reference}

1. O. Dobrzhanskyi, Yu. Makar, O. Masan, Khotynshchyna: Istorychnyi narys [Khotynshchyna: Historical Essay], Chernivtsi, Molodyi bukovynets, 2002, s. 56.

2. A. Yurchenko. Khotinskoye vosstaniye ( $\mathrm{K}$ istorii borby krestian severnoy Bessarabii protiv avstro-vengerskikh i rumynskikh okkupantov v 1918 - 1919 gg.) [Khotyn Uprising (On the History of the Struggle of the Peasants of Northern Bessarabia against the Austro-Hungarian and Romanian invaders in 1918 - 1919)], Kiyev, Ukrainskoye izdatelstvo politicheskoy literatury, 1948, s. 38.

3. A. Yurchenko, Khotinskoye vosstaniye, s. 38-39.

4. A. Yurchenko, Khotinskoye vosstaniye, s. 40.

5. A. Yurchenko, Khotinskoye vosstaniye, s. 42.

6. A. Yurchenko, Khotinskoye vosstaniye, s. 43.

7. Khotinskoye vosstaniye (Sbornik dokumentov i materialov) [Khotyn Uprising (Collection of Documents and Materials)], Kishinev, Shtiintsa, 1976, s. 3.

8. Khotinskoye vosstaniye (Sbornik dokumentov i materialov), s. 56-57, 285-292.

9. K.H. Tsypko, Velyka Zhovtneva sotsialistychna revoliutsiia i borotba trudiashchykh Bukovyny za vladu Rad ta vozziednannia z Radianskoiu Ukrainoiu [Great October Socialist Revolution and Struggle of the Working People of Bukovyna for the Power of Soviets and Reunion with Soviet Ukraine], Chernivtsi, MVO URSR, Chernivetskyi derzhavnyi universytet, 1958, c. 97-98.

10. I. Piddubnyi, Materialy Tsentralnoho derzhavnoho arkhivu vyshchykh orhaniv vlady ta upravlinnia Ukrainy pro podii 1918 - 1919 pp. u Khotynskomu poviti [Materials of the Central State Archive of the Supreme Governments and Government of Ukraine on the Events of 1918 - 1919 in Khotyn District], in «Istorychna panorama», Chernivtsi, 2009, ch. 2, http://www.info-library.com.ua/books-text-10329.html

11. Bukovyna: istorychnyi narys, [Bukovyna: Historical Essay], Chernivtsi, Zelena Bukovyna, 1998, c. 221.

12. O. Dobrzhanskyi, Yu. Makar, O. Masan, Khotynshchyna: Istorychnyi narys, s. 193.

13. Bukovyna $v$ konteksti yevropeiskykh mizhnarodnykh vidnosyn (z davnikh chasiv do seredyny XX st.) [Bukovyna in the Context of European International Relations (Since Ancient Times to the Middle of the XX century)], Chernivtsi, Ruta, 2005, c. 378.

14. Narysy istorii derzhavnoi sluzhby v Ukraini, [Essays on the History of Civil Service in Ukraine], Kyiv, NikaTsentr, 2008, s. 190; Derzhavnyi vistnyk (Kyiv), 1918, №6, 26 travnia, s. 1.

15. Derzhavnyi vistnyk (Kyiv), 1918, №7, 29 travnia, s. 1.

16. Narysy istorii derzhavnoi sluzhby v Ukraini, s. 192-193.

17. Derzhavnyi vistnyk (Kyiv), 1918, №36, 17 serpnia, s. 3.

18. Derzhavnyi vistnyk (Kyiv), 1918, №8, 31 travnia, s. 1.

19. Derzhavnyi vistnyk (Kyiv), 1918, №8, 31 travnia, s. 3.

20. Derzhavnyi vistnyk (Kyiv), 1918, №16, 18 chervnia, s. 1.

21. S.L. Kalytko, O.M. Kravchuk, Podillia u period hetmanatu 1918 r.: konservatyvna model vnutrishno politychnoi stabilizatsii [Podilia During the Hetmanate of 1918: a Conservative Model of Internal Political Stabilization], in 
«Naukovi zapysky Vinnytskoho derzhavnoho pedahohichnoho universytetu imeni Mykhaila Kotsiubynskoho. Seriia: Istoriia», 2008, vyp. 13, s. 246.

22. M. Hedin, Ukrainsko-rumunski vidnosyny naperedodni ta $\mathrm{v}$ period hetmanuvannia Pavla Skoropadskoho [Ukrainian-Romanian Relations on the Eve of and During Hetmanization of Pavlo Skoropadskyi], in «Visnyk Kyivskoho natsionalnoho linhvistychnoho universytetu. Ser.: Istoriia, ekonomika, filosofiia», 2012, vyp. 17, s. 111.

23. Derzhavnyi vistnyk (Kyiv), 1918, №12, 9 chervnia, s. 2.

24. I. Piddubnyi, Materialy Tsentralnoho derzhavnoho arkhivu vyshchykh orhaniv vlady ta upravlinnia Ukrainy pro podii 1918 - 1919 pp. u Khotynskomu poviti, http://www.info-library.com.ua/books-text-10329.html

25. Formuvannia ta diialnist mistsevykh derzhavnykh administratsii ta samovriaduvannia $\mathrm{v}$ period Ukrainskoi revoliutsii 1917 - 1920 rr.: materialy kruhloho stolu, m. Kamianets-Podilskyi, 2 lypnia 2015 r., KamianetsPodilskyi, 2015, s. 42-43.

26. Derzhavnyi vistnyk (Kyiv), 1918, №23, 18 lypnia, s. 2.

27. A. Yurchenko, Khotinskoye vosstaniye, s. 122.

28. I. Piddubnyi, Materialy Tsentralnoho derzhavnoho arkhivu vyshchykh orhaniv vlady ta upravlinnia Ukrainy pro podii 1918 - 1919 pp. u Khotynskomu poviti, http://www.info-library.com.ua/books-text-10329.html

29. O.M. Kravchuk, I.I. Ratushniak, K.V. Zavalniuk, Podilskyi hubernskyi starosta Serhii Kyselov (1877 - 1937) u dokumentakh epokhy [Podilia Provincial Starosta Serhii Kiselov $(1877$ - 1937) in the documents of the epoch], Vinnytsia, TOV «Nilan-LTD», 2016, c. 126.

30. A. Yurchenko, Khotinskoye vosstaniye, s. 38.

31. A. Yurchenko, Khotinskoye vosstaniye, s. 126.

32. Khotinskoye vosstaniye (Sbornik dokumentov i materialov), c. 286.

33. Khotinskoye vosstaniye (Sbornik dokumentov i materialov), c. 286.

34. Khotinskoye vosstaniye (Sbornik dokumentov i materialov), c. 287.

35. A. Yurchenko, Khotinskoye vosstaniye, s. 43.

36. A. Yurchenko, Khotinskoye vosstaniye, s. 42.

37. A. Yurchenko, Khotinskoye vosstaniye, s. 129.

38. A. Yurchenko, Khotinskoye vosstaniye, s. 129.

39. A. Yurchenko, Khotinskoye vosstaniye, s. 129.

40. O.M. Kravchuk, I.I. Ratushniak, K.V. Zavalniuk, Podilskyi hubernskyi starosta Serhii Kyselov (1877 - 1937) u dokumentakh epokhy [Podilia Provincial Starosta Serhii Kiselov $(1877$ - 1937) in the documents of the epoch], Vinnytsia, TOV «Nilan-LTD», 2016, c. 199-200.

41. S.L. Kalytko, O.M. Kravchuk, Podillia u period hetmanatu 1918 r.: konservatyvna model vnutrishno politychnoi stabilizatsii [Podilia During the Hetmanate of 1918: a Conservative Model of Internal Political Stabilization], in «Naukovi zapysky Vinnytskoho derzhavnoho pedahohichnoho universytetu imeni Mykhaila Kotsiubynskoho. Seriia: Istoriia», 2008, vyp. 13, s. 249.

42. Derzhavnyi vistnyk (Kyiv), 1918, №3, 21 travnia, s. 2. 